\title{
Familiarity with Caspian Kutum (Rutilus kutum)
}

\author{
Mohammad Forouhar Vajargah* \\ Department of Fisheries - Faculty of Natural Resources - University of Guilan, Iran \\ ${ }^{*}$ Corresponding author: Dr. Mohammad Forouhar Vajargah, Department of Fisheries - Faculty of Natural Resources - University of Guilan, Iran; Email: \\ mohammad.forouhar@yahoo.com
}

Received: December 29, 2021; Accepted: January 03, 2022; Published: January 05, 2022

\begin{abstract}
Caspian kutum is one of the valuable and economical species in the Caspian Sea basin, which in most years of exploitation accounts for half of the amount of bony fish catch and has two forms of autumn and spring, the spring form of most of the stocks of this fish gives. These reserves have decreased due to various reasons such as irresponsible fishing, changes in the water level of the Caspian Sea, construction of dams, etc., and for this reason, they have resorted to artificial reproduction of this fish to compensate for this issue. It is an Anadromoys and migrates to the river to reproduce when it reaches sexual maturity and then returns to the sea. After spawning and returning to the sea, Caspian kutum feed on the shallow shores of the Caspian Sea, a land rich in benthic animals, for the remainder of spring and summer. In late summer, due to the very high temperature, Caspian kutum leave the shallow shores and live in deeper places, and when the autumn temperature rotates, they return to the shallow parts of the shores with a depth of less than 20 meters for feeding.
\end{abstract}

Keywords: Kutum, Caspian Sea, Anadromoys

\section{Introduction}

The Caspian Sea is the largest lake in the world and the unique and major habitat of Caspian kutum [1-4]. Caspian kutum is a bony fish belonging to the family Cyprinidae of the genus Rutilus with the scientific name of Rutilus kutum, a native fish of the Caspian Sea. Caspian kutum are migratory and rudimentary and spend most of their lives in the salty waters of the sea and migrate to the fresh water of the river every year in the spring (mid-March to the end of May) for spawning and reproduction [5].

Caspian kutum food is very diverse and numerous, in fact Caspian kutum is omnivorous and gluttonous. The intensity of feeding varies at different times, for example during reproductive times and when they migrate to the river to lay eggs, and the intestines of these fish are often thick and empty, and also in late winter and with decreasing temperature, this index decreases sharply Finds [6].

\section{Sexual Management of Caspian kutum}

Sexual maturity in fish is affected by various environmental factors such as temperature, length of light period, water salinity and various other factors. Changes in these factors can have adverse effects on fish reproduction [7].

\section{Sexual Intercourse Consists of Six Stages}

\section{Stage 1 - Immature}

Very small sexual organs close to the spine, testicles and ovaries transparent and grayish in color, eggs invisible to the naked eye (ovogony)

\section{Stage 2 - Immature}

In the testicles and ovaries are semi-transparent, gray, half or slightly more than half the length of the abdominal area, the eggs are solitary and with a visible magnifying glass, spawning fish (resting) are placed in this class (Primary eggs).

\section{Stage 3 - Developing}

The testicles and ovaries are dark, reddish with blood capillaries occupy half of the abdomen and the eggs are visible to the naked eye in the form of copper grains. (Hollow eggs)

\section{Stage 4 - Preparation for Spawning}

The genitals fill the abdominal area and the testicles are white, the sperm fluid is shed due to pressure and the eggs are completely round and some are semi-transparent.

\section{Stage 5 - Spawning}

Eggs and sperm are released at low pressure, most of the eggs are translucent with a number of clear eggs.

\section{Stage 6 - Spawning}

The ovaries are loose and wrinkled, the abdomen is completely empty and the eggs are empty [8].

\section{Migration of Spring and Autumn forms of Caspian kutum}

The maximum age of Caspian kutum is 9 to 10 years and its maximum weight is 5 to $6 \mathrm{~kg}$. Male Caspian kutum mature at three years old and female Caspian kutum at four years old. Caspian kutum spawn on aquatic plants as well as on bedrock rocks and pebbles. Spawning peaks of spring Caspian kutum occur in April and May, when the water temperature is between 13 and 15 degrees Celsius. 
After migrating to the sea, Caspian kutum spend their feeding and growth stages in the sea and after reaching the age of sexual maturity, they enter the fresh water environment of Anzali wetland and the rivers leading to the Caspian Sea for natural reproduction and reproduction.

Autumn migratory Caspian kutum, if the conditions are right, usually enter the sea from early October and through the canal, first the male fish and then the females. The Shijan region in the eastern lagoon spends time in deep areas and then, as the weather warms up in late winter, they migrate to rivers that are covered with marginal vegetation such as reeds and loess, and carry out propagation operations on them, which is why the reason for this form of Caspian kutum is called phytophilus. But now the main population of Caspian kutum in the Caspian Sea belongs to the spring form, which accounts for more than $98 \%$ of the reserves [9].

\section{Artificial Reproduction}

The annual extraction rate of Caspian kutum from 1980 to 2006 was between 8 to 11 thousand tons per year. Comparison of these release and catch values shows that during the last 30 years, more Caspian kutum stocks have been provided as a result of artificial reproduction, and the available evidence indicates that during this period, the natural reproduction conditions of Caspian kutum become more unsuitable every year and the share of natural reproduction in existing reserves Caspian kutum in the Caspian Sea have been declining to a very small extent. Caspian kutum feed and grow in the sea and after reaching sexual maturity are used for spawning in very few rivers as the main places for spawning and artificial reproduction of this species. Reconstruction of reserves involves capturing part of the population and reproducing them in captivity and releasing them into the wild. In this method, the broods are caught from the rivers of the Caspian Sea and after artificial reproduction, the fertilized eggs are transferred to the breeding center and finally the larvae weighing $2 \mathrm{~g}$ are released into the sea, thus the annual fishing center has about 200 million The larvae are produced through artificial reproduction and this release plays a key role in restoring the stocks of this species [10-12].

\section{References}

1. Kouchesfahani NE, Vajargah MF (2021) A SHORT REVIEW ON THE BIOLOGICAL CHARACTERISTICS OF THE SPECIES ESOX LUCIUS, LINNAEUS, 1758 IN CASPIAN SEA BASIN (IRAN). Transylvanian Review of Systematical \& Ecological Research 23: 73-80.

2. Forouhar Vajargah M, Sattari M, Imanpour Namin J, Bibak M (2021) Evaluation of trace elements contaminations in skin tissue of Rutilus kutum Kamensky 1901 from the south of the Caspian Sea. Journal of Advances in Environmental Health Research 9: $139-148$.

3. Forouhar Vajargah M, Sattari M, Imanpour Namin J, Bibak M (2020) Length-weight, length-length relationships and condition factor of Rutilus kutum (Actinopterygii: Cyprinidae) from the southern Caspian Sea, Iran. Journal of Animal Diversity 2: 56-61.

4. Vajargah MF, Sattari M, Namin JI, Bibak M (2021) Predicting the Trace Element Levels in Caspian Kutum (Rutilus kutum) from south of the Caspian Sea Based on Locality, Season and Fish Tissue. Biological Trace Element Research 200: 354-363. [crossref]

5. Vajargah MF, Mohsenpour R, Yalsuyi AM, Galangash MM, Faggio C (2021) Evaluation of Histopathological Effect of Roach (Rutilus rutilus caspicus) in Exposure to Sub-Lethal Concentrations of Abamectin. Water, Air, \& Soil Pollution 232: 1-8.
6. Sattari M, Vajargah MF, Bibak M, Bakhshalizadeh S (2020) Relationship between Trace Element Content in the Brain of Bony Fish Species and Their Food Items in the Southwest of the Caspian Sea Due to Anthropogenic Activities. Avicenna Journal of Environmental Health Engineering 7: 78-85.

7. Forouhar Vajargah M, Sattari M, Imanpour J, Bibak M (2020) Length-weight relationship and some growth parameters of Rutilus kutum (Kaminski 1901) in the South Caspian Sea. Experimental animal Biology 9: 11-20.

8. Sattari M, Namin JI, Bibak M, Vajargah MF, Hedayati A, et al. (2019) Morphological comparison of western and eastern populations of Caspian kutum, Rutilus kutum (Kamensky, 1901)(Cyprinidae) in the southern Caspian Sea. International Journal of Aquatic Biology 6: 242-247.

9. Sattari M, Imanpour Namin J, Bibak M, Forouhar Vajargah M, Bakhshalizadeh S, et al. (2020) Determination of trace element accumulation in gonads of Rutilus kutum (Kamensky, 1901) from the south Caspian Sea trace element contaminations in gonads. Proceedings of the National Academy of Sciences, India Section B: Biological Sciences 90: 777-784.

10. Vajargah MF, Hedayati A, Yalsuyi AM, Abarghoei S, Gerami MH, et al. (2014) Acute toxicity of Butachlor to Caspian Kutum (Rutilus frisii Kutum Kamensky, 1991). Journal of Environmental Treatment Techniques 2: 155-157.

11. Sattari M, Bibak M, Forouhar Vajargah M (2020) Evaluation of trace elements contaminations in muscles of Rutilus kutum (Pisces: Cyprinidae) from the Southern shores of the Caspian Sea. Environmental Health Engineering and Management Journal 7: 89-96.

12. Forouhar Vajargah M, Bibak M (2021) Pollution zoning on the southern shores of the Caspian Sea by measuring metals in Rutilus kutum tissue. Biological Trace Element Research 1-11. [crossref]

\section{Citation:}

Vajargah MF (2022) Familiarity with Caspian Kutum (Rutilus kutum). Aquac Fish Stud Volume 4(1): 1-2. 